\title{
Symbiotic immuno-suppression: Is disease susceptibility the price of bleaching resistance?
}

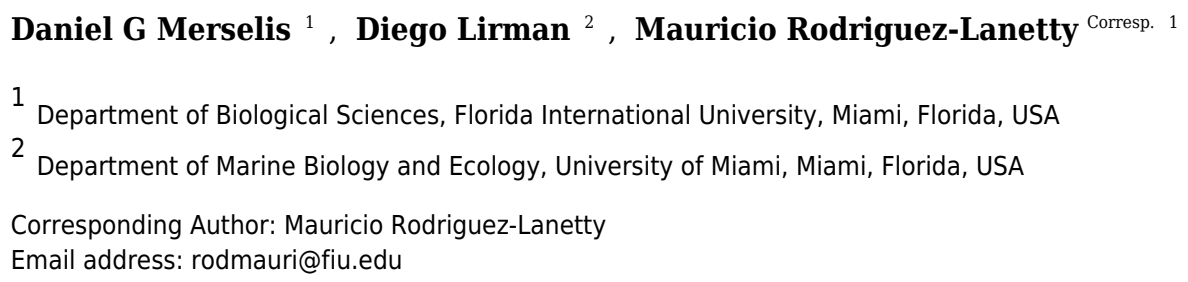

Accelerating anthropogenic climate change threatens to destroy coral reefs worldwide through the processes of bleaching and disease. These major contributors to coral mortality are both closely linked with thermal stress intensified by anthropogenic climate change. Disease outbreaks typically follow bleaching events, but a direct positive linkage between bleaching and disease has been debated. By tracking 152 individual coral ramets through the 2014 mass bleaching in a South Florida coral restoration nursery, we revealed a highly significant negative correlation between bleaching and disease in the Caribbean staghorn coral, Acropora cervicornis. To explain these results, we propose a mechanism for transient immunological protection through coral bleaching: Removal of Symbiodinium during bleaching may also temporarily eliminate suppressive symbiont modulation of host immunological function. We contextualize this hypothesis within an ecological perspective in order to generate testable predictions for future investigation. 
1 Symbiotic Immuno-suppression: Is Disease Susceptibility the Price of

2 Bleaching Resistance?

3 Daniel G Merselis ${ }^{1}$, Diego Lirman ${ }^{2}$, and Mauricio Rodriguez-Lanetty ${ }^{1}$

4 1. Department of Biological Sciences, Florida International University, Miami, USA

5 2. Department of Marine Biology and Ecology, University of Miami, Miami, USA

6 Running Title: Symbiotic Immuno-Suppresion

7 Abstract 
8 Accelerating anthropogenic climate change threatens to destroy coral reefs worldwide through

9 the processes of bleaching and disease. These major contributors to coral mortality are both

10 closely linked with thermal stress intensified by anthropogenic climate change. Disease outbreaks

11 typically follow bleaching events, but a direct positive linkage between bleaching and disease has

12 been debated. By tracking 152 individual coral ramets through the 2014 mass bleaching in a

13 South Florida coral restoration nursery, we revealed a highly significant negative correlation

14 between bleaching and disease in the Caribbean staghorn coral, Acropora cervicornis. To explain

15 these results, we propose a mechanism for transient immunological protection through coral

16 bleaching: Removal of Symbiodinium during bleaching may also temporarily eliminate

17 suppressive symbiont modulation of host immunological function. We contextualize this

18 hypothesis within an ecological perspective in order to generate testable predictions for future

19 investigation. 
21 Anthropogenic climate change threatens to destroy coral reefs globally before the end of the

22 century (Hoegh-Guldberg et al. 2007; Hoegh-Guldberg 2014). Increasing frequency, severity, and

23 duration of thermal anomalies have caused increased coral bleaching and disease outbreaks

24 (Harvell et al. 1999; Harvell et al. 2002; Bruno et al. 2007; Hoegh-Guldberg and Bruno 2010;

25 Ruiz-Moreno et al. 2012; Randall and van Woesik 2015). Coral bleaching represents the

26 breakdown of the obligate mutualism between dinoflagellates of the genus Symbiodinium and

27 reef building corals. This breakdown results in decreased coral growth, fecundity, and

28 survivorship, as the loss of photosynthetic Symbiodinium deprives corals of up to 95\% of their

29 energetic budget (Muscatine and Porter 1977; Glynn 1983; Harriott 1985; Goreau and

30 Macfarlane 1990; Szmant and Gassman 1990; Baird and Marshall 2002). Coral tissue-loss

31 disease outbreaks frequently follow bleaching events (Harvell et al. 2001; Muller et al. 2008;

32 Brandt and Mcmanus 2009; Cróquer and Weil 2009; Miller et al. 2009; Precht et al. 2016; Lewis

33 et al. 2017) and, like bleaching, are linked to thermal anomalies (Selig et al. 2006; Bruno et al.

34 2007; Brandt and McManus 2009; Cróquer and Weil 2009; Ban et al. 2012; Ruiz-Moreno et al.

35 2012) as well as poor water quality (Haapkylä et al. 2011; Vega Thurber et al. 2014). Many of

these diseases remain poorly characterized and may represent the invasion of one or more

37 opportunistic microbes or viruses (see Lesser et al. 2007 and Bourne et al. 2009). Koch's

postulates have been fulfilled for several coral diseases, but some of these same diseases have

later been induced by alternative etiological agents, indicating that signs of coral maladies may 2014). Like bleaching, coral tissue loss diseases can cause coral mortality, reduce coral growth and fecundity, and are recognized as major drivers of coral reef decline (Richardson et al. 1998;

44 Harvell et al. 2001; Patterson et al. 2002; Miller et al. 2006; Weil et al. 2009; Miller et al. 2009) 
45 Coral tissue loss diseases (as opposed to diseases resultant in discoloration or abnormal growth

46 form) are the focus of this study.

47 Whether tissue loss disease outbreaks follow bleaching events on a correlational or causal basis is

48 a topic of debate (Bruno et al. 2007; Muller et al. 2008; Brandt and McManus 2009; Cróquer and

49 Weil 2009; Ban et al. 2012). A causal relationship between the two conditions is intuitive as

50 starvation induced by bleaching could lead towards increased coral host susceptibility. Muller et

51 al. (2008) and others demonstrated that a relationship between temperature and disease

52 prevalence could be found during a bleaching year as opposed to non-bleaching years and further

53 correlated that mortality due to disease was correlated to temperature in bleached, but not

54 unbleached corals. Furthermore, there is a relationship between mean percentage of bleached

55 corals and prevalence of several diseases in numerous Caribbean scleractinian genera (Brandt and

56 McManus 2009; Cróquer and Weil 2009). These relationships correlate bleaching and disease,

57 but do not necessarily link them mechanistically. The co-occurrence of bleaching and tissue loss

58 diseases is expected even if the two conditions are mechanistically independent, because

59 bleaching and tissue loss diseases are both enhanced by thermal stress (Glynn and D'Croz 1990;

60 Bruno et al. 2007; Lesser 2011). Monitoring at the population level can indicate correlation

61 between bleaching and disease, but cannot be used to prove a mechanistic link. A causal

62 relationship between bleaching and disease would leave a pattern of co-occurrence when

63 monitored at the individual level (i.e. bleached individuals should have significantly greater rates

64 of disease). As such, monitoring efforts which perform repeated transects without tracking

65 individuals may be unable to differentiate a causal or correlational relationship (Cróquer and Weil

66 2009). Population and community level co-observation between bleaching and disease linked by

67 a common environmental driver should not be construed as a dependency between them. 
68 Contrary to this expected pattern of correlation, white band disease on the Great Barrier Reef has

69 had a negative spatial correlation to bleaching events, even though the disease was correlated

70 with thermal anomaly (Bruno et al. 2007). Further, geographically predictive models for white

71 syndrome outbreaks are not improved by the incorporation of information known to accurately

72 predict coral bleaching (Ban et al. 2012). This work suggests a correlational rather than causal

73 relationship, because these disease outbreaks are not enhanced by prior bleaching.

74 At a physiological level, immunological markers respond to bleaching conflictingly; prophenol

75 oxidase and peroxidase activity may increase during bleaching, while phenol oxidase, lysozyme-

76 like, and microbial antibacterial activity decline (Ritchie 2006; Mydlarz et al. 2009; Palmer et al.

77 2011). The coral mucus layer acts both as a physical barrier to infection and a point of first

78 contact/adhesion for an infectious agent (Banin et al. 2001; Brown and Bythell 2005). It is largely

79 produced with resources from Symbiodinium, and its production is therefore dependent upon the

80 mutualism between Symbiodinium and coral host(Brown and Bythell 2005).

81 In the present study, monitoring for bleaching and tissue loss disease was carried out in

82 restoration nursery. Coral nurseries provide a unique opportunity for monitoring, because

83 histories of environmental conditions and genetic backgrounds is known in these common

84 gardens(Lirman and Schopmeyer 2016). Mother colonies are often fragmented many times,

85 resulting in clonal individual colonies known as ramets ideal for replication. The collection of all

86 these clonal ramets descendant from a single mother colony are known as a genet, although this is

87 frequently referred to as a genotype in the restoration literature (Baums 2008).

88 Individual Acropora cervicornis ramets were monitored during a bleaching event and subsequent

89 recovery in an in situ coral nursery located near Miami, Florida, USA to elucidate patterns of

90 correlation between bleaching and disease (Lirman et al. 2014). All of the ramets tracked had

91 been at the nursery (common garden) for at least 3 years prior to the onset of bleaching. 
92 We hypothesized that bleached ramets should be more susceptible to disease than their

93 unbleached counterparts and that certain coral genets would have genetic pre-dispositions

94 towards disease and bleaching resistance or susceptibility. Our results confirmed our hypothesis

95 regarding the effect of genet. However, to our surprise, results revealed a significant negative

96 correlation between bleaching and disease. These findings lead us to postulate a model whereby

97 Symbiodinium may suppress host immunity. According to this theoretical framework, bleaching

98 events may be associated with a transient increase in host immunological capacity, despite the

99 nutritionally detrimental loss of Symbiodinium.

\section{Materials and Methods}

101 The strong El Niño Southern Oscillation (ENSO) event that occurred in 2014 triggered mass

102 coral bleaching events and subsequent disease outbreaks in the Greater Caribbean and the Florida

103 Reef Tract (Manzello 2015; Precht et al. 2016; Lewis et al. 2017). Ramets of A. cervicornis

104 propagated since 2007 within the in situ University of Miami "North Nursery" at N 25.488; W

10580.109 were monitored by the same observer using SCUBA at four time points (September and

106 November 2014, January, and March 2015) under permits SAL-14-1086-SCRP, BISC-2014-SCI-

107 0018, and BISC-2015-SCI-0018.

108 Within the nursery, multiple ramets belonging to the same genet grow on individual pedestals

109 raised off of a common cement block. Each block containing clonal ramets belonging to the same

110 genet rests on a sand bottom all within approximately 100 meters of each other at an approximate

111 depth of 7 meters. No ramets were in physical contact for the duration of the study. During the

112 bleaching event and subsequent recovery, lasting from September 2014 through March 2015, 152

113 ramets representing $21 \mathrm{~A}$. cervicornis genets were tracked. These genets were previously 
114 genotyped and identified as genetically distinct using microsatellite markers (Baums et al. 2005;

115 Baums et al. 2009; Lirman et al. 2014). During every time point, each ramet was photographed

116 and scored for presence or absence of bleaching using a calibrated colorimetric card as a

117 reference (Siebeck et al. 2006). Any visible presence of disease was also recorded when an easily

118 discernible linear boundary between apparently normally pigmented (tan to brown) tissue and

119 transparent tissue and visible skeleton was observed. Each ramet was then assigned to one of the

120 following categories based upon observations: "bleaching without disease", "bleaching with

121 disease", "no bleaching without disease", or "no bleaching with disease". Manifestation of a

122 tissue loss condition was noted as disease, because it followed a linear progression of tissue loss

123 from the base progressing towards the tips in a manner similar to white band disease. However,

124 our study did not fully explore the pathogenesis of this phenomenon and it should properly be

125 referred to as a tissue loss disease. The individual history of one ramet throughout the entire

126 duration of the study was considered the experimental unit, so that if a ramet bleached, recovered,

127 and later experienced disease, it was grouped as "bleaching with disease" even though bleaching

128 and tissue-loss conditions never co-occurred. A fisher's exact test was employed to detect

129 significant effect of genet on likelihood of bleaching or disease. To determine which genets were

130 significantly different from each other, a Bonferroni corrected pair wise fisher's exact test was

131 performed. A Chi squared test for independence was carried out to determine whether bleaching

132 and disease were correlated or independent. Expected values were calculated for each category

133 based upon the null hypothesis that bleaching and disease were fully independent as follows:

$134 \mathbf{O}_{\mathrm{B}}=$ observed $\%$ of ramets bleached

$135 \mathbf{O}_{\% \mathrm{D}}=$ observed $\%$ of ramets with disease

$136 \mathrm{O}_{\% \mathrm{~B} \& \mathrm{D}}=$ observed $\%$ of ramets bleached and diseased 
137 Bleaching without disease $=\left(\mathbf{O}_{\% \mathrm{~B}}-\mathbf{O}_{\% \mathrm{~B} \& \mathrm{D}}\right) \mathrm{X}$ total ramets

138 Disease without bleaching $=\left(\mathbf{O}_{\% \mathrm{D}}-\mathbf{O}_{\% \mathrm{~B} \& \mathrm{D}}\right) \mathrm{X}$ total ramets

139 Bleaching with disease $=\mathbf{O}_{\% \text { в }}$ X $\mathbf{O}_{\% \text { D }} \mathrm{X}$ total ramets

140 No Bleaching or disease $=\left(1-\left(\mathbf{O}_{\% \mathrm{~B} \& \mathrm{D}}+\mathbf{O}_{\% \mathrm{D}}+\mathbf{O}_{\% \mathrm{~B}}\right)\right) \mathrm{X}$ total ramets

141 Genets (9 of 21) that contained neither a bleached nor a diseased ramet over the entire duration of

142 the study were removed from statistical analyses. We reasoned that these genets lacking

143 vulnerability to both bleaching and disease are unsuitable for studying the interaction of

144 bleaching and disease(Vollmer and Kline 2008). Expected values for each test were calculated

145 based upon the pool of observations inclusive of all those genets analyzed by each respective test.

146 Only genets which showed neither bleaching nor disease in all of their ramets were removed from 147 analyses.

\section{Results}

149 In September 2014, nine ramets were bleached while fourteen ramets were affected by a white

150 band-like tissue loss disease. In November 2014, four ramets were bleached, while one experienced tissue loss. In January 2014, two ramets were bleached and an additional two were afflicted by tissue loss. In March 2015, both bleaching and tissue loss disease increased in

153 prevalence to eight and eleven cases, respectively (Fig. 1). During the entire period, 19 of the 152 $154(12.5 \%)$ A. cervicornis ramets showed signs of bleaching, while 28 ramets $(18.4 \%)$ showed signs 
155 of this tissue loss disease. Only one ramet (0.7\%) showed signs of both bleaching in Sept 2014

156 and disease recorded in March 2015, though pigmentation had recovered prior to the onset of

157 disease. No ramet with simultaneous bleaching and disease was ever observed.

158 The tissue loss disease appeared to follow a linear progression from the base towards

159 the apical tips of ramets in a manner reminiscent of white band disease (Fig. 2). However,

160 molecular analyses necessary to confirm the identity of the disease were not conducted and the

161 disease we observed is henceforth referred to as a "tissue loss disease". Furthermore, preliminary

162 transmission trials bringing unaffected ramets into contact with the active lesions were unable to

163 induce transmission although a linear progression of tissue loss was apparent. A highly significant

164 negative correlation was detected between the presence of bleaching and disease $\left(\chi^{2}=7.14\right.$,

$165 \mathrm{p}=0.0075)$. In total, nine of the 21 genets did not contain a single ramet suffering from either

166 bleaching or disease during the monitoring period. There were significant differences between

167 genets' proportion of ramets bleached, diseased, neither bleached nor diseased, or both bleached

168 and diseased despite limited statistical power to detect a medium sized effect $(\mathrm{p}<0.0001,1$ -

$169 \beta=0.31$, Figure. 3)(Cohen 1992).

\section{Discussion}

171 Focusing on a ramet by ramet basis, our study revealed a negative correlation between bleaching

172 and tissue loss disease during the thermal event in 2014 while simultaneously documenting a

173 positive temporal relationship between bleaching and disease at a population scale (Fig. 1). While

174 negative correlation between bleaching and a tissue loss disease has been previously documented

175 (Bruno et al. 2007), ours is the first report that shows a negative correlation between bleaching

176 and a tissue loss disease in individually tracked ramets. 
177 Previous work has indicated that coral genet identity influences diverse host phenotypes such as

178 bleaching susceptibility, disease resistance, growth rate, and morphology (Willis and Ayre 1985;

179 Vollmer and Kline 2008; Bowden-Kerby and Carne 2012; Lirman et al. 2014). Our study further

180 contributes to the body of genotypic response literature, suggesting that host genotype is a

181 significant factor to consider for effective conservation and restoration. Unfortunately, the limited

182 statistical power of our analyses may have contributed to our detection of relatively few

183 significant comparisons (figure 3). A much larger analysis including 443 ramets equally

184 distributed amongst genets would have provided a much greater statistical power of 0.90 , but was

185 beyond the scope of the current study.

186 Despite the great importance of coral host genetics in determining both bleaching and

187 disease resistance, presence of genets susceptible to only one of the two conditions and resistant

188 to the other does not appear to have solely driven the negative correlation between bleaching and

189 disease. This is evident especially in genets A, J, R, and W (figure 3) which contain both ramets

190 that suffered from disease and other ramets that suffered from bleaching, although never at the

191 same time (recall that the ramet classified as bleached and diseased in genet W first bleached and

192 became diseased only after recovering from bleaching). Such a pattern suggests that unbleached

193 ramets within these genets later suffered increased disease susceptibility relative to their clones.

194 The role of Symbiodinium identity has also been strongly implicated in physiological

195 response to bleaching and disease (Baker 2004; Tchernov et al. 2004; LaJeunesse et al. 2009;

196 Silverstein et al. 2014; Rouzé et al. 2016). Results from a representative subset of samples taken

197 from diverse genets indicate that no ramet had greater than a minimal $(<2 \%)$ variance from

198 exclusively hosting type A3 Symbiodinium (Merselis et al., in prep). Therefore, we suggest that

199 host genetics, not Symbiodinium identity is responsible for observed significant differences

200 between genets. Not only do genet dependent differences in physiology inform which genets will 
201 do best in response to one or two focal stressors, but more importantly, which genets we are

202 likely to lose. Given the precipitous decline of Caribbean reefs, and Acropora cervicornis in

203 particular, we suggest that surviving genets likely posses anthropogenically robust traits, even if a

204 study on any one given stressor indicates susceptibility. These differential responses should

205 motivate not only the crossing of very bleaching or disease resistant genets, but also the inclusion

206 of genets clearly at risk, but likely possessing unknown resistances to other anthropogenic

207 stressors.

208 While increased sample size would have benefited analysis at the genet level and probably

209 allowed for the detection of more significant differences $(1-\beta=0.31)$, physiology must be studied

210 at the level of the individual (in this case ramet). Without knowledge of the history of an

211 individual gathered over multiple time points, it is not possible to ascertain whether an individual

212 was not affected by bleaching or disease, suffered only bleaching, suffered only disease, or was

213 afflicted by both bleaching and disease. When individuals are not tracked, but the prevalence of

214 bleaching and tissue loss diseases are followed, it is clear that disease and bleaching are linked

215 through time during temperature anomalies. (Fig. 1 of this study; and Muller et al. 2008).

216 However, because both bleaching and many tissue loss diseases are dependent upon temperature

217 as a common stressor, it is expected that they should co-occur along spatial and temporal scales

218 (Fig. 1), sharing high incidence where thermal stress has been severe and low incidence where

219 thermal stress is mild (Muller et al. 2008). Without data to show that individuals and not just

220 populations are first affected by bleaching and then disease, a physiological link cannot be

221 supported. As exemplified here, when data is presented on an individual basis along a time series,

222 it is possible that those individuals that bleach may be less prone to disease despite temporal co-

223 occurrence within the population. We suggest it is possible that a negative correlation between

224 bleaching and tissue loss diseases on an individual basis may have been overlooked by previous 
225 investigations, because individuals were not tracked across multiple time points (Cróquer and

226 Weil 2009). Monitoring individual corals (ramets) within a common garden nursery allowed us

227 to control against co-occurrence of bleaching and tissue loss diseases as a result of spatial

228 variation in environmental conditions while enabling repeated assessment of individuals with

229 known bleaching and disease history.

230 A possible explanatory mechanism for a negative correlation between bleaching and tissue loss

231 diseases may hinge upon the immuno-suppressive nature of intracellular symbioses. Intracellular

232 parasites and mutualists modulate host immunological defenses in order to facilitate their

233 intracellular lifestyles (Oster et al. 1978; Fytrou et al. 2006; Douglas et al. 2011; Ratzka et al.

234 2012; Zheng et al. 2014). Examples are diverse including Rickettsea (Oster et al. 1978),

235 Walbachea (Fytrou et al. 2006), Buchnera (Douglas et al. 2011), Spiroplasma (Herren and

236 Lemaitre 2011), Sodalis, Wigglesworthia (reviewed in Ratzka et al. 2012), and Plasmodium

237 (reviewed in Zheng et al. 2014), a distant relative of Symbiodinium that interferes with cellular

238 processes to prevent apoptosis (Kaushansky et al. 2013a; Kaushansky et al. 2013b).

239 Further evidence is apparent within Symbiodinium - Cnidarian symbioses. Cnidarians hosting

240 Symbiodinium express an altered distribution and expression of Rab proteins when compared to

241 their apo-symbiotic con-specifics. This alternative regulation of Rab proteins preserves the

242 symbiosis by preventing the maturation of the symbiosome, the vacuole where the symbiont

243 resides, into a lysosome (Chen et al. 2004; Riesgo et al. 2014). This same dysregulation

244 mechanism possibly impairs the ability for phagosomal degradation of pathogens by cnidarians

245 hosting Symbiodinium. Further, apoptosis, an important immune response, is down-regulated in

246 symbiotic versus aposymbiotic sea anemones (Rodriguez-Lanetty et al. 2006; Oakley et al. 2016;

247 Matthews et al. 2017)Medrano et al., in prep), while potential cell adhesion markers facilitating 
248 pathogen entry are upregulated (Rodriguez-Lanetty et al. 2006; Yuyama et al. 2010; Riesgo et al.

249 2014). This leads us to think that Symbiodinium containing host cells are immune-suppressed.

250 Symbiodinium may also promote immunological tolerance of their cnidarian hosts. Exogenous

251 application of tolerogenic factors both decreases immune response of Exaiptasia pallida and

252 prevents it from bleaching under elevated temperatures, while the treatment with an anti-

253 tolerogenic factor prevents symbiosis establishment and stimulates host immune function

254 (Detournay et al. 2012; Berthelier et al. 2017). Recently, anthozoan TGF $\beta$ receptor and other

255 modulators of immune response were proven to be regulated by Symbiodinium produced

256 miRNAs in hospite(Baumgarten et al. 2017). Likewise, many immunological processes lead to

257 the generation of ROS, a primary trigger of coral bleaching (Lesser 1996), suggesting that corals

258 with high capacity for immunological response may be more susceptible to bleaching. Therefore,

259 corals with the highest immunological activity at the onset of thermal stress may be at an elevated

260 risk of bleaching (Brandt and Mcmanus 2009). A host previously lacking in Symbiodinium may

261 be better prepared to confront invading pathogenic microbes. Conversely, corals better prepared

262 to confront invading microbes may be more likely to expel their symbionts as a side effect of an

263 immune response.

264 Under our proposed model (see Fig. 4), bleaching corals gain a transient immunological

265 advantage as a result of shedding their symbionts. Despite disparate thermal bleaching thresholds

266 both between and amongst species, genotypes, and geographic locations, little is known about the

267 "trade-off" or ecological cost for increased bleaching resistance, although a slower growth rate

268 for bleaching resistant genotypes has been supported for Acropora cervicornis (Ladd et al. 2017).

269 We suggest that our proposed model is a trade-off of decreased bleaching resistance in exchange

270 for enhanced immunological function and vise versa. 
271 It is important to note that immunological responses are metabolically costly. Bleaching reduces

272 or completely stops the assimilation of Symbiodinium derived nutrition. Therefore, the

273 immunological capacity of a bleached coral would eventually be hindered by decreasing

274 energetic reserves. The model, which assumes that Symbiodinium density is directly related to

275 immune-suppression, illustrates that corals would have evolved to consider immunological

276 capacity when setting a bleaching threshold, alongside tolerance for oxidative and thermal stress.

277 By setting a high bleaching threshold, corals forego the putative immunological advantages of

278 bleaching, but retain Symbiodinium until their antioxidant protections against thermal stress

279 become overwhelmed. This strategy would maintain higher energetic reserves and may prove

280 more successful under long term thermal stress scenarios where energetic reserves may become

281 limiting to the maintenance of homeostatic processes and immunological capacity. Conversely,

282 corals may set a low bleaching threshold to protect against infectious disease in the short term at

283 the risk of susceptibility to starvation if thermal stress is long term and prevents the re-population

284 of Symbiodinium. Corals exploiting this latter strategy suffer ongoing pathogen exposures or

285 thermal stress and may be forced to recover symbiont populations in order to prevent starvation.

286 Resultantly, these corals simultaneously suffer the onset of Symbiodinium mediated

287 immunological suppression and depleted energetic stores. In congruence with field observations,

288 this is perhaps why disease outbreaks may intensify upon the onset of bleaching recovery (Brandt

289 and McManus 2009). In further agreement with field observations, those corals which bleach and

290 are still unable to prevent the onset of disease outbreaks would be expected to suffer the greatest

291 tissue loss (Muller et al. 2008; Brandt and McManus 2009). These corals lack both the

292 immunological competency to prevent infectious disease and the energetic stores to mount a

293 sustained response. Also in agreement with field observations, Symbiodinium densities are greater

294 on eutrophied reefs which also have greater tissue loss disease prevalence (Muscatine et al. 1989;

295 Shantz and Burkepile 2014; Vega Thurber et al. 2014). It is worth noting that reefs with more 
296 frequent thermal anomaly are known both for their bleaching resistance and white syndrome

297 susceptibility, although it should also be noted that they are more susceptible to brown spot

298 disease (Hume et al. 2013; Fine et al. 2013; Palumbi et al. 2014; Randall et al. 2014).

299 Here, in addition to proposing a new model for infectious disease susceptibility in the context of 300 coral bleaching, we establish a testable hypothesis: Coral bleaching confers a transient

301 immunological advantage to the coral host. While the present study's sample size is limited and 302 canonical logic has historically supported a causal and positive relationship between bleaching 303 and tissue loss diseases, our proposed hypothesis is supported by molecular work and alternative 304 interpretations of several field studies. Further testing is warranted, especially as reefs are 305 exposed to increasingly frequent and intense thermal anomalies. Beyond our proposed 306 hypothesis, this study adds further support to numerous works demonstrating the importance of 307 coral host genotype in determination of diverse physiological traits.

308 Acknowledgements:

309 The authors thank Dr. Kuulei Rodgers, Dr. Tanya Brown, Dr. Anthony Bellantuono, Ms. Ellen 310 Dow, Ms. Cindy Lewis, Mr. Daniel Quintero, and two anonymous reviewers, whose comments 311 improved this manuscript, Stephanie Schopmeyer, Crawford Drury, Dalton Hesley, and Patricia 312 Waikel for diving logistical support, and Dr. Wensong Wu for statistical advice.

\section{Literature Cited}

314 Baird a., Marshall P. 2002. Mortality, growth and reproduction in scleractinian corals following bleaching on the Great Barrier Reef. Marine Ecology Progress Series 237:133-141. DOI: 
317 Baker AC. 2004. Corals' adaptive response to climate change. Nature 430:2004.

318 Ban SS., Graham NAJ., Connolly SR. 2012. Relationships between temperature, bleaching and 319 white syndrome on the Great Barrier Reef. Coral Reefs 32:1-12. DOI: 10.1007/s00338-012$320 \quad$ 0944-6.

321

322

323

Banin E., Israely T., Fine M., Loya Y., Rosenberg E. 2001. Role of endosymbiotic zooxanthellae and coral mucus in the adhesion of the coral-bleaching pathogen Vibrio shiloi to its host. FEMS Microbiology Letters 199:33-37. DOI: 10.1016/S0378-1097(01)00162-8.

Baumgarten S., Cziesielski MJ., Thomas L., Michell CT., Esherick LY., Pringle JR., Aranda M., Voolstra CR. 2017. Evidence for miRNA $\square$ mediated modulation of the host transcriptome in cnidarian $\square$ dinoflagellate symbiosis. Molecular Ecology. DOI: 10.1111/mec.14452.

Baums IB. 2008. A synopsis of coral restoration genetics. In: Advances in Coral Husbandry in Public Aquariums. Public Aquarium Husbandry Series. 335-338.

Baums I., Devlin-Durante K., Brown L., Pinzon JH. 2009. Nine novel, polymorphic microsatellite markers for the study of threatened Caribbean acroporid corals. Molecular ecology resources 9:1155-1158. DOI: 10.1111/j.1755-0998.2009.02588.x.

Baums IB., Miller MW., Hellberg ME. 2005. Regionally isolated populations of an imperiled Caribbean coral, Acropora palmata. Molecular Ecology 14:1377-1390. DOI: 10.1111/j.1365-294X.2005.02489.x.

Berthelier J., Schnitzler CE., Wood-Charlson EM., Poole AZ., Weis VM., Detournay O. 2017. Implication of the host TGF $\beta$ pathway in the onset of symbiosis between larvae of the coral Fungia scutaria and the dinoflagellate Symbiodinium sp. (clade C1f). Coral Reefs 36:12631268. DOI: $10.1007 / \mathrm{s} 00338-017-1621-6$. 
339 Bourne DG., Garren M., Work TM., Rosenberg E., Smith GW., Harvell CD. 2009. Microbial 340 disease and the coral holobiont. Trends in Microbiology 17:554-562. DOI:

$341 \quad$ 10.1016/j.tim.2009.09.004.

342

343

344

345

346

347

348

Bowden-Kerby A., Carne L. 2012. Thermal Tolerance as a factor in Caribbean Acropora Restoration. In: Proceedings of the 12th International Coral Reef Symposium. 9-13.

Brandt ME., Mcmanus JW. 2009. Disease incidence is related to bleaching extent in reef-building corals. Ecology 90:2859-2867. DOI: 10.1890/08-0445.1.

Brandt M., McManus J. 2009. Disease incidence is related to bleaching extent in reef-building corals. Ecology 90:2859-2867.

Brown BE., Bythell JC. 2005. Perspectives on mucus secretion in reef corals. Marine Ecology Progress Series 296:291-309. DOI: 10.3354/meps296291.

Bruno JF., Selig ER., Casey KS., Page C a., Willis BL., Harvell CD., Sweatman H., Melendy AM. 2007. Thermal stress and coral cover as drivers of coral disease outbreaks. PLoS biology 5:e124. DOI: 10.1371/journal.pbio.0050124.

Chen MC., Cheng YM., Hong MC., Fang LS. 2004. Molecular cloning of Rab5 (ApRab5) in Aiptasia pulchella and its retention in phagosomes harboring live zooxanthellae. Biochemical and Biophysical Research Communications 324:1024-1033. DOI: 10.1016/j.bbrc.2004.09.151.

Cohen J. 1992. A power primer. Psychological Bulletin 112:155-159. DOI: 10.1037/00332909.112.1.155.

Cróquer A., Weil E. 2009. Changes in Caribbean coral disease prevalence after the 2005 bleaching event. Diseases of Aquatic Organisms 87:33-43. DOI: 10.3354/dao02164. 
361 Denner EBM., Smith GW., Busse HJ., Schumann P., Narzt T., Polson SW., Lubitz W., Richardson

362 LL. 2003. Aurantimonas coralicida gen. nov., sp. nov., the causative agent of white plague

363 type II on Caribbean scleractinian corals. International Journal of Systematic and

364 Evolutionary Microbiology 53:1115-1122. DOI: 10.1099/ijs.0.02359-0.

365 Detournay O., Schnitzler CE., Poole A., Weis VM. 2012. Regulation of cnidarian-dinoflagellate

366 mutualisms: Evidence that activation of a host TGF $\beta$ innate immune pathway promotes

367 tolerance of the symbiont. Developmental and comparative immunology 38:525-37. DOI:

$368 \quad$ 10.1016/j.dci.2012.08.008.

369 Douglas AE., Bouvaine S., Russell RR. 2011. How the insect immune system interacts with an

$370 \quad$ obligate symbiotic bacterium. Proceedings. Biological sciences / The Royal Society

$371 \quad 278: 333-8$. DOI: $10.1098 / \mathrm{rspb} .2010 .1563$.

372 Fine M., Gildor H., Genin A. 2013. A coral reef refuge in the Red Sea. Global change biology 19:3640-7. DOI: 10.1111/gcb.12356.

Fytrou A., Schofield PG., Kraaijeveld AR., Hubbard SF. 2006. Wolbachia infection suppresses both host defence and parasitoid counter-defence. Proceedings of the Royal Society B: Biological Sciences 273:791-796. DOI: 10.1098/rspb.2005.3383.

Glynn P. 1983. Extensive“ bleaching” and death of reef corals on the Pacific coast of Panama. Environmental Conservation 10:149-154.

Glynn PW., D’Croz L. 1990. Experimental evidence for high temperature stress as the cause of El Niño-coincident coral mortality. Coral Reefs 8:181-191. DOI: 10.1007/BF00265009.

Goreau TJ., Macfarlane a. H. 1990. Coral Reefs following the 1987-1988 coral-bleaching event. Coral Reefs 8:211-215. DOI: 10.1007/BF00265013. 
383 Haapkylä J., Unsworth RKF., Flavell M., Bourne DG., Schaffelke B., Willis BL. 2011. Seasonal 384 rainfall and runoff promote coral disease on an inshore reef. PLoS ONE 6:1-10. DOI: $385 \quad$ 10.1371/journal.pone.0016893.

Harriott V. 1985. Mortality rates of scleractinian corals before and during a mass bleaching event. Marine Ecology Progress Series 21:81-88. DOI: 10.3354/meps021081.

Harvell D., Kim K., Burkholder JM., Colwell RR., Epstein PR., Grimes DJ., Hoffman EE., Lipp EK., Osterhause ADME., Overstreet RM., Porter JW., Smith GW., Vasta GR. 1999. Emerging Marine Diseases: Climate Links and Anthropogenic Factors. Science:1505-1510.

Harvell D., Kim K., Quirolo C., Weir J., Smith G. 2001. Coral bleaching and disease: contributors to 1998 mass mortality in Briareum asbestinum (Octocorallia, Gorgonacea). The Ecology and Etiology of Newly Emerging Marine Diseases:97-104.

Harvell CD., Mitchell CE., Ward JR., Altizer S., Dobson AP., Ostfeld RS., Samuel MD. 2002. Climate Warming and Disease Risks for Terrestrial and Marine Biota. Science 296:21582162. DOI: 10.1126/science.1063699.

Herren JK., Lemaitre B. 2011. Spiroplasma and host immunity: Activation of humoral immune responses increases endosymbiont load and susceptibility to certain Gram-negative bacterial pathogens in Drosophila melanogaster. Cellular Microbiology 13:1385-1396. DOI: 10.1111/j.1462-5822.2011.01627.x.

Hoegh-Guldberg O. 2014. Coral reef sustainability through adaptation: glimmer of hope or persistent mirage? Current Opinion in Environmental Sustainability 7:127-133. DOI: 10.1016/j.cosust.2014.01.005.

Hoegh-Guldberg O., Bruno JF. 2010. The impact of climate change on the world's marine ecosystems. Science (New York, N.Y.) 328:1523-8. DOI: 10.1126/science.1189930. 
406 Hoegh-Guldberg O., Mumby PJ., Hooten a J., Steneck RS., Greenfield P., Gomez E., Harvell

407 CD., Sale PF., Edwards a J., Caldeira K., Knowlton N., Eakin CM., Iglesias-Prieto R., 408 Muthiga N., Bradbury RH., Dubi a., Hatziolos ME. 2007. Coral reefs under rapid climate 409 change and ocean acidification. Science (New York, N.Y.) 318:1737-42. DOI:

$410 \quad 10.1126 /$ science.1152509.

411 Hume B., D’Angelo C., Burt J., Baker a C., Riegl B., Wiedenmann J. 2013. Corals from the 412 Persian/Arabian Gulf as models for thermotolerant reef-builders: Prevalence of clade C3 413 Symbiodinium, host fluorescence and ex situ temperature tolerance. Marine pollution $414 \quad$ bulletin 72:313-22. DOI: 10.1016/j.marpolbul.2012.11.032.

415 Kaushansky A., Metzger PG., Douglass AN., Mikolajczak SA., Lakshmanan V., Kain HS., Kappe 416 SH. 2013a. Malaria parasite liver stages render host hepatocytes susceptible to mitochondria-initiated apoptosis. Cell death \& disease 4. DOI: 10.1038/cddis.2013.286.

Kaushansky A., Ye AS., Austin LS., Mikolajczak SA., Vaughan AM., Camargo N., Metzger PG., Douglass AN., MacBeath G., Kappe SHI. 2013b. Suppression of Host p53 Is Critical for Plasmodium Liver-Stage Infection. Cell Reports 3:630-637. DOI: 10.1016/j.celrep.2013.02.010.

Ladd M., Shantz A., Bartels E., Burkepile D. 2017. Thermal stress reveals a genotype-specific tradeoff between growth and tissue loss in restored Acropora cervicornis. Marine Ecology Progress Series 572.

428

LaJeunesse TC., Smith RT., Finney J., Oxenford H. 2009. Outbreak and persistence of opportunistic symbiotic dinoflagellates during the 2005 Caribbean mass coral "bleaching" event. Proceedings. Biological sciences / The Royal Society 276:4139-48. DOI: 10.1098/rspb.2009.1405. 
429

430

431

432

433

434

435

436

437

438

439

440

441

442

443

444

445

446

447

448

449

450

451

Lesser MP. 1996. Elevated temperatures and ultraviolet radiation cause oxidative stress and inhibit photosynthesis in symbiotic dinoflagellates. Limnology and Oceanography 41:271283. DOI: 10.4319/1o.1996.41.2.0271.

Lesser MP. 2011. Coral Bleaching: Causes and Mechanisms. In: Coral Reefs: An Ecosystem in Transition. Dordrecht: Springer Netherlands, 405-419. DOI: 10.1007/978-94-007-0114$4 \_23$.

Lesser MP., Bythell JC., Gates RD., Johnstone RW., Hoegh-Guldberg O. 2007. Are infectious diseases really killing corals? Alternative interpretations of the experimental and ecological data. Journal of Experimental Marine Biology and Ecology 346:36-44. DOI: 10.1016/j.jembe.2007.02.015.

Lesser MP., Jarett JK. 2014. Culture-dependent and culture-independent analyses reveal no prokaryotic community shifts or recovery of Serratia marcescens in Acropora palmata with white pox disease. FEMS Microbiology Ecology 88:457-467. DOI: 10.1111/15746941.12311.

Lewis CL., Neely KL., Richardson LL., Rodriguez-Lanetty M. 2017. Temporal dynamics of black band disease affecting pillar coral (Dendrogyra cylindrus) following two consecutive hyperthermal events on the Florida Reef Tract. Coral Reefs 36:427-431. DOI: $10.1007 / \mathrm{s} 00338-017-1545-1$.

Lirman D., Schopmeyer S. 2016. Ecological solutions to reef degradation: optimizing coral reef restoration in the Caribbean and Western Atlantic. PeerJ 4:e2597. DOI: 10.7717/peerj.2597.

Lirman D., Schopmeyer S., Galvan V., Drury C., Baker AC., Baums IB. 2014. Growth dynamics of the threatened Caribbean staghorn coral Acropora cervicornis: influence of host genotype, symbiont identity, colony size, and environmental setting. PloS one 9:e107253. 
DOI: 10.1371/journal.pone.0107253.

453

454

Manzello DP. 2015. Rapid recent warming of coral reefs in the Florida Keys. Scientific Reports 5:16762. DOI: 10.1038/srep16762.

Matthews JL., Crowder CM., Oakley CA., Lutz A., Roessner U., Meyer E., Grossman AR., Weis VM., Davy SK. 2017. Optimal nutrient exchange and immune responses operate in partner specificity in the cnidarian-dinoflagellate symbiosis. Proceedings of the National Academy of Sciences:201710733. DOI: 10.1073/pnas.1710733114.

Miller J., Muller E., Rogers C., Waara R., Atkinson a., Whelan KRT., Patterson M., Witcher B. 2009. Coral disease following massive bleaching in 2005 causes $60 \%$ decline in coral cover on reefs in the US Virgin Islands. Coral Reefs 28:925-937. DOI: 10.1007/s00338-009-05317.

Miller J., Waara R., Muller E., Rogers C. 2006. Coral bleaching and disease combine to cause extensive mortality on reefs in US Virgin Islands. Coral Reefs 25:418-418. DOI:

$$
10.1007 / \mathrm{s} 00338-006-0125-6 .
$$

Muller EM., Rogers CS., Spitzack a. S., van Woesik R. 2008. Bleaching increases likelihood of disease on Acropora palmata (Lamarck) in Hawksnest Bay, St John, US Virgin Islands. Coral Reefs 27:191-195. DOI: 10.1007/s00338-007-0310-2.

Muscatine L., Falkowski PG., Dubinsky Z., Cook P., McCloskey LR. 1989. The Effect of External Nutrient Resources on the Population Dynamics of Zooxanthellae in a Reef Coral. Proceedings. Biological sciences / The Royal Society 236:311-324.

Muscatine L., Porter J. 1977. Reef corals: mutualistic symbioses adapted to nutrient-poor environments. Bioscience 27:454-460. 
474 Mydlarz LD., Couch CS., Weil E., Smith G., Harvell CD. 2009. Immune defenses of healthy, 475 bleached and diseased Montastraea faveolata during a natural bleaching event. Diseases of $476 \quad$ Aquatic Organisms 87:67-78. DOI: 10.3354/dao02088.

477 Oakley CA., Ameismeier MF., Peng L., Weis VM., Grossman AR., Davy SK. 2016. Symbiosis 478 induces widespread changes in the proteome of the model cnidarian Aiptasia. Cellular 479 Microbiology 18:1009-1023. DOI: 10.1111/cmi.12564.

480 Oster CN., Kenyon RH., Pedersen CEJ. 1978. Suppression of cellular immune responses in 481 guinea pigs infected with spotted fever group rickettsiae. Infection and immunity 22:411482417.

483 Palmer C V., Bythell JC., Willis BL. 2011. A comparative study of phenoloxidase activity in 484 diseased and bleached colonies of the coral Acropora millepora. Developmental and 485 Comparative Immunology 35:1098-1101. DOI: 10.1016/j.dci.2011.04.001.

486 Palumbi SR., Barshis DJ., Traylor-Knowles N., Bay RA. 2014. Mechanisms of Reef Coral 487 Resistance to Future Climate Change. Science 344:895-898. DOI: 10.1071/MF99078.

Patterson KL., Porter JW., Ritchie KB., Polson SW., Mueller E., Peters EC., Santavy DL., Smith GW. 2002. The etiology of white pox, a lethal disease of the Caribbean elkhorn coral, Acropora palmata. Proceedings of the National Academy of Sciences of the United States of America 99:8725-30. DOI: 10.1073/pnas.092260099.

Precht WF., Gintert BE., Robbart ML., Fura R., van Woesik R. 2016. Unprecedented DiseaseRelated Coral Mortality in Southeastern Florida. Scientific Reports 6:31374. DOI: $10.1038 /$ srep31374.

Randall CJ., Jordan-Garza AG., Muller EM., Van Woesik R. 2014. Relationships between the history of thermal stress and the relative risk of diseases of Caribbean corals. Ecology 
498

499

500

501

502

503

504

505

506

507

508

509

510

511

512

513

514

515

516

517

518

Randall CJ., van Woesik R. 2015. Contemporary white-band disease in Caribbean corals driven by climate change. Nature Climate Change 5:DOI: 10.1038/NCLIMATE2530. DOI:

$$
\text { 10.1038/nclimate2530. }
$$

Ratzka C., Gross R., Feldhaar H. 2012. Endosymbiont tolerance and control within insect hosts. Insects 3:553-572. DOI: 10.3390/insects3020553.

Richardson LL., Goldberg WM., Carlton R., Halas JC. 1998. Coral disease outbreak in the Florida Keys: Plague Type II. Rev. Biol. Trop. 46:187-198.

Riesgo A., Peterson K., Richardson C., Heist T., Strehlow B., McCauley M., Cotman C., Hill M., Hill A. 2014. Transcriptomic analysis of differential host gene expression upon uptake of symbionts: a case study with Symbiodinium and the major bioeroding sponge Cliona varians. BMC genomics 15:376. DOI: 10.1186/1471-2164-15-376.

Ritchie K. 2006. Regulation of microbial populations by coral surface mucus and mucusassociated bacteria. Marine Ecology Progress Series 322:1-14. DOI: 10.3354/meps322001.

Rodriguez-Lanetty M., Phillips WS., Weis VM. 2006. Transcriptome analysis of a cnidariandinoflagellate mutualism reveals complex modulation of host gene expression. $B M C$ genomics 7:23. DOI: 10.1186/1471-2164-7-23.

Rouzé H., Lecellier G., Saulnier D., Berteaux-Lecellier V. 2016. Symbiodinium clades A and D differentially predispose Acropora cytherea to disease and Vibrio spp. colonization. Ecology and Evolution 6:560-572. DOI: 10.1002/ece3.1895.

Ruiz-Moreno D., Willis BL., Page a C., Weil E., Cróquer A., Vargas-Angel B., Jordan-Garza AG., Jordán-Dahlgren E., Raymundo L., Harvell CD. 2012. Global coral disease prevalence 

100:249-61. DOI: 10.3354/dao02488.

521

Selig ER., Harvell CD., Bruno JF., Willis BL., Page a C., Casey KA., Sweatman H. 2006. Analyzing the relationship between ocean temperature anomalies and coral disease outbreaks at broad spatial scales. In: Phinney J, Hoegh-Guldberg O, Kleypas J, Skirving W eds. Coral reefs and climate change: science and managemen. Washington, DC: American Geophysical Union, 111-128. DOI: 10.1029/61CE07.

Shantz AA., Burkepile DE. 2014. Context-dependent effects of nutrient loading on the coral-algal mutualism. Ecology 95:1995-2005. DOI: 10.1890/13-1407.1.

Siebeck UE., Marshall NJ., Klüter a., Hoegh-Guldberg O. 2006. Monitoring coral bleaching using a colour reference card. Coral Reefs 25:453-460. DOI: 10.1007/s00338-006-0123-8.

Silverstein RN., Cunning R., Baker AC. 2014. Change in algal symbiont communities after bleaching, not prior heat exposure, increases heat tolerance of reef corals. Global change biology:1-14. DOI: 10.1111/gcb.12706.

Sunagawa S., DeSantis TZ., Piceno YM., Brodie EL., DeSalvo MK., Voolstra CR., Weil E., Andersen GL., Medina M. 2009. Bacterial diversity and White Plague Disease-associated community changes in the Caribbean coral Montastraea faveolata. The ISME journal 3:512-521. DOI: 10.1038/ismej.2008.131.

Sutherland KP., Shaban S., Joyner JL., Porter JW., Lipp EK. 2011. Human pathogen shown to cause disease in the threatened eklhorn coral Acropora palmata. PLoS ONE 6. DOI: 10.1371/journal.pone.0023468.

Szmant A., Gassman N. 1990. The effects of prolonged "bleaching" on the tissue biomass and reproduction of the reef coral Montastrea annularis. Coral reefs 8:217-224. 
542 Tchernov D., Gorbunov MY., de Vargas C., Narayan Yadav S., Milligan AJ., Haggblom M.,

543 Falkowski PG. 2004. Membrane lipids of symbiotic algae are diagnostic of sensitivity to

544 thermal bleaching in corals. Proceedings of the National Academy of Sciences 101:13531-

545 13535. DOI: $10.1073 /$ pnas.0402907101.

546 Vega Thurber RL., Burkepile DE., Fuchs C., Shantz AA., Mcminds R., Zaneveld JR. 2014.

547 Chronic nutrient enrichment increases prevalence and severity of coral disease and

548 bleaching. Global Change Biology 20:544-554. DOI: 10.1111/gcb.12450.

549 Vollmer S V., Kline DI. 2008. Natural disease resistance in threatened staghorn corals. PLoS

550 ONE 3:1-5. DOI: 10.1371/journal.pone.0003718.

551 Weil E., Cróquer A., Urreiztieta I. 2009. Yellow band disease compromises the reproductive

552 output of the Caribbean reef-building coral Montastraea faveolata (Anthozoa, Scleractinia).

553 Diseases of Aquatic Organisms 87:45-55. DOI: 10.3354/dao02103.

554 Willis BL., Ayre DJ. 1985. Asexual reproduction and genetic determination of growth form in the 555 coral Pavona cactus: biochemical genetic and immunogenic evidence. Oecologia:516-525.

556 Yuyama I., Watanabe T., Takei Y. 2010. Profiling Differential Gene Expression of Symbiotic and 557 Aposymbiotic Corals Using a High Coverage Gene Expression Profiling (HiCEP) Analysis. 558 Marine Biotechnology 13:32-40. DOI: 10.1007/s10126-010-9265-3.

559 Zheng H., Tan Z., Xu W. 2014. Immune evasion strategies of pre-erythrocytic malaria parasites. $560 \quad$ Mediators of Inflammation 2014. DOI: 10.1155/2014/362605.

\section{Captions for figures:}


562 Figure 1: Monthly prevalence of bleached and diseased coral ramets of Acropora cervicornis 563 between September 2014 and March 2015 in the "North Nursery" at Biscayne Bay (N 25.488; W $56480.109)$.

565 Figure 2: Examples of bleaching and diseased colonies of Acropora cervicornis within the North 566 Nursery. A) Several ramets, some of which show normal, healthy pigmentation $(\mathrm{H})$, while others 567 are bleached pale (P). B) One ramet showing signs of a linearly progressing tissue loss disease.

568 Figure 3: Frequency of health status in Acropora cervicornis corals as a function of genet 569 identity. Genet identity has a significant effect on the probability for each studied health status $570(\mathrm{p}<0.0001)$. Shared letters between genets indicate no significant difference. Both the trend for 571 fewer significant comparisons and low statistical power $1-\beta=0.31$ suggest that more significant 572 differences could have been detected with a larger sample size.

573 Figure 4: Predicted relative immunological vulnerability assuming Symbiodinium have an 574 immunosuppressive affect on the coral host. A) A coral which does not bleach in response to a 575 stress event may see immunological vulnerability increase until the stress event subsides. B) A 576 coral which bleaches and does not recover is free from symbiont immunosuppression, but 577 eventually becomes immunologically vulnerable because of energy store deprivation. C) A coral 578 which bleaches and recovers may minimize Symbiodinium immunosuppression in the short term, 579 but suffer from reduced energy stores and immunosuppression of returning Symbiodinium upon 580 recovery. 
Figure 1

Monthly prevalence of bleached and diseased coral ramets of Acropora cervicornis Monthly prevalence of bleached and diseased coral ramets of Acropora cervicornis between September 2014 and March 2015 in the "North Nursery" at Biscayne Bay (N 25.488; W 80.109).

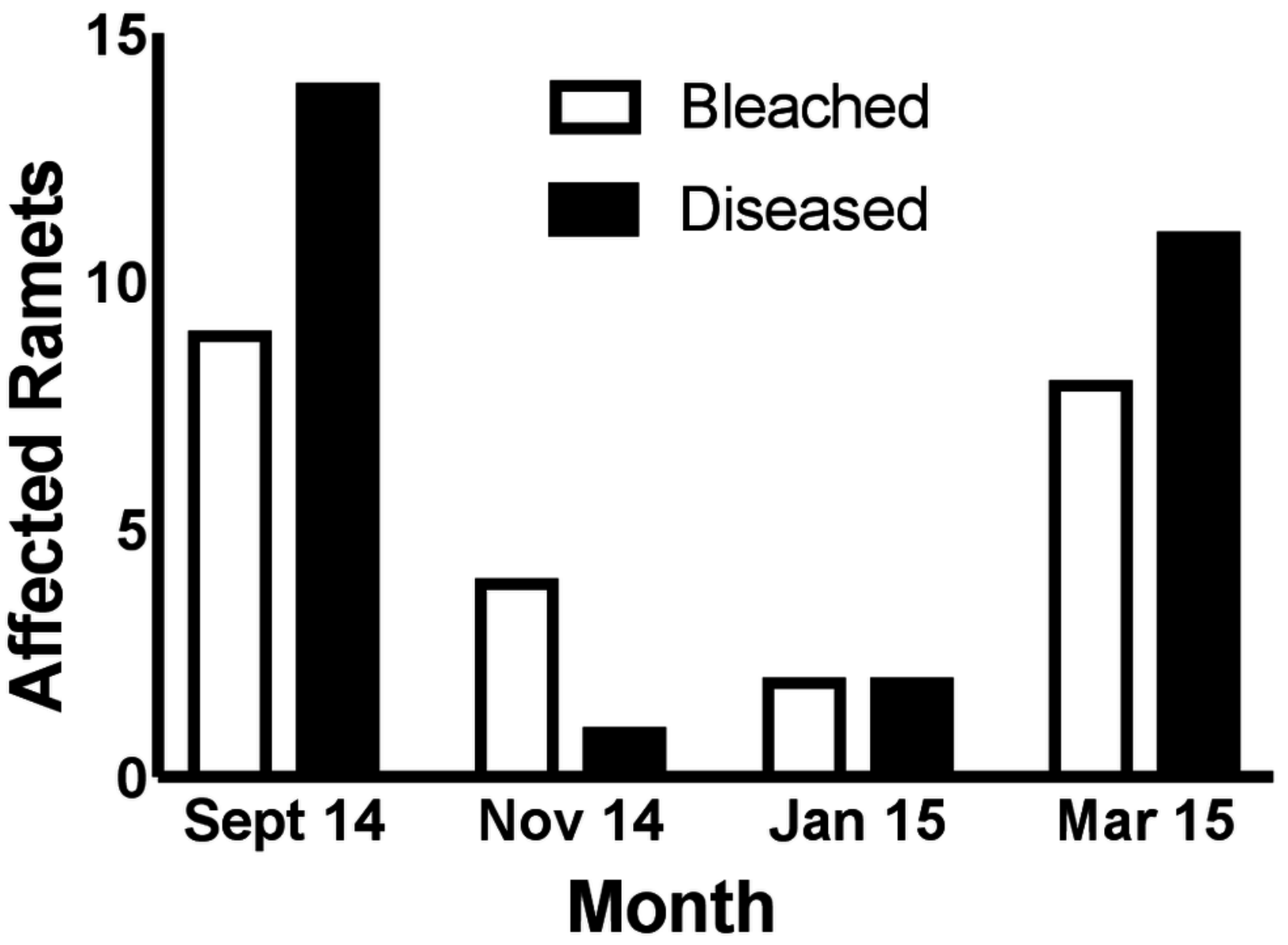




\section{Figure 2}

Images of bleaching and diseased colonies of Acropora cervicornis within the North Nursery.

Examples of bleaching and diseased colonies of Acropora cervicornis within the North Nursery. A) Several ramets, some of which show normal, healthy pigmentation $(H)$, while others are bleached pale (P). B) One ramet showing signs of white band-like white syndrome. Photographs taken by Stephanie Schopmeyer.

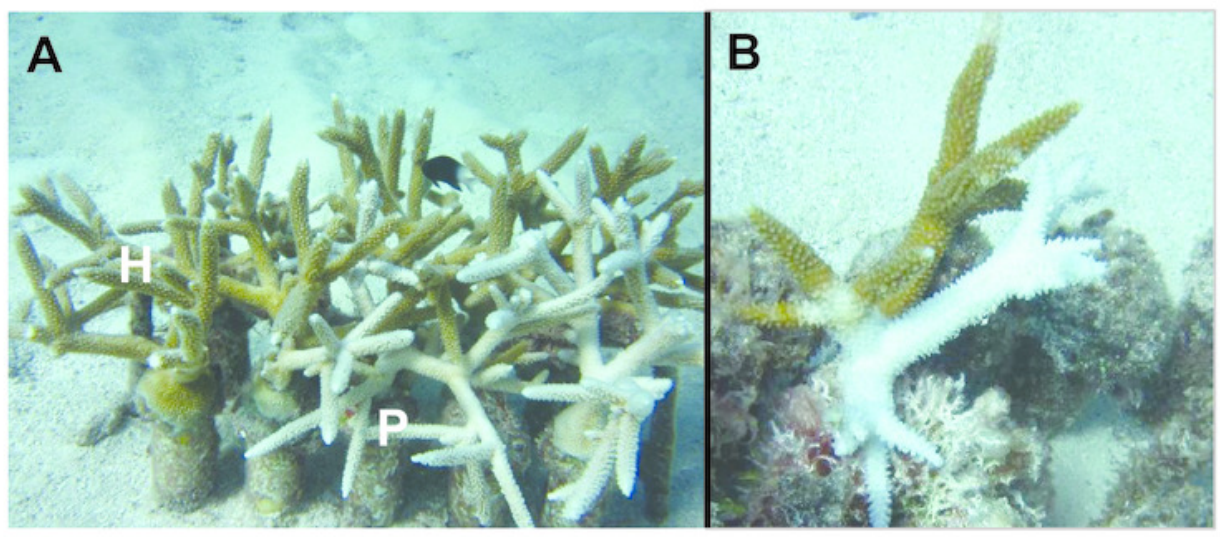


Figure 3

Frequency of health status in Acropora cervicornis corals as a function of genet identity.

Genet identity has a significant effect on the probability for each studied health status $(p<0.0001)$. Shared letters between genets indicate no significant difference. Both the trend for fewer significant comparisons and low statistical power 1- $\beta=0.31$ suggest that more significant differences could have been detected with a larger sample size.

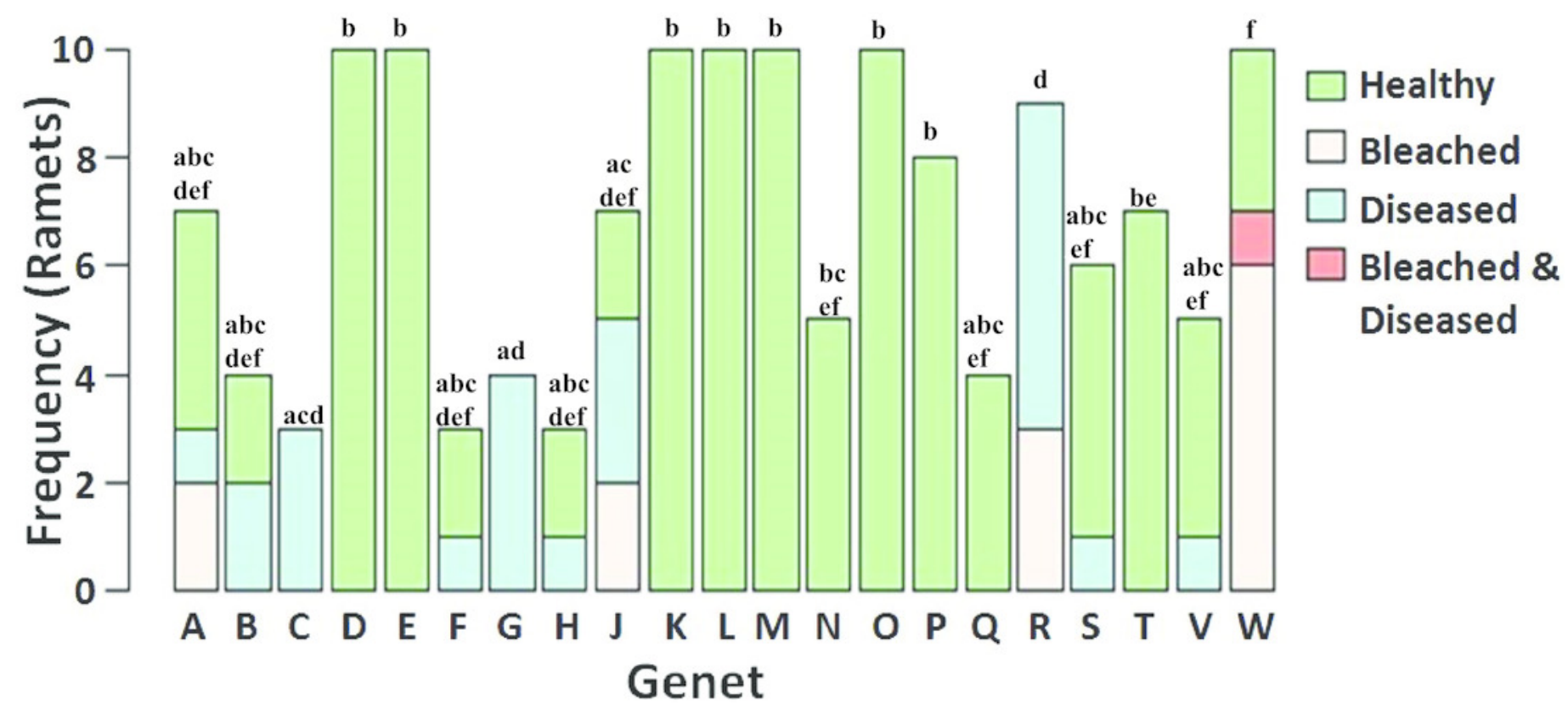




\section{Figure 4}

Predicted relative immunological vulnerability assuming Symbiodinium have an immunosuppressive affect on the coral host.

A) A coral, which does not bleach in response to a stress event may see immunological vulnerability increase until the stress event subsides. B) A coral, which bleaches and does not recover is free from symbiont immunosuppression, but eventually becomes immunologically vulnerable because of energy store deprivation. C) A coral, which bleaches and recovers may minimize Symbiodinium immunosuppression in the short term, but suffer from reduced energy stores and immunosuppression of returning Symbiodinium upon recovery.

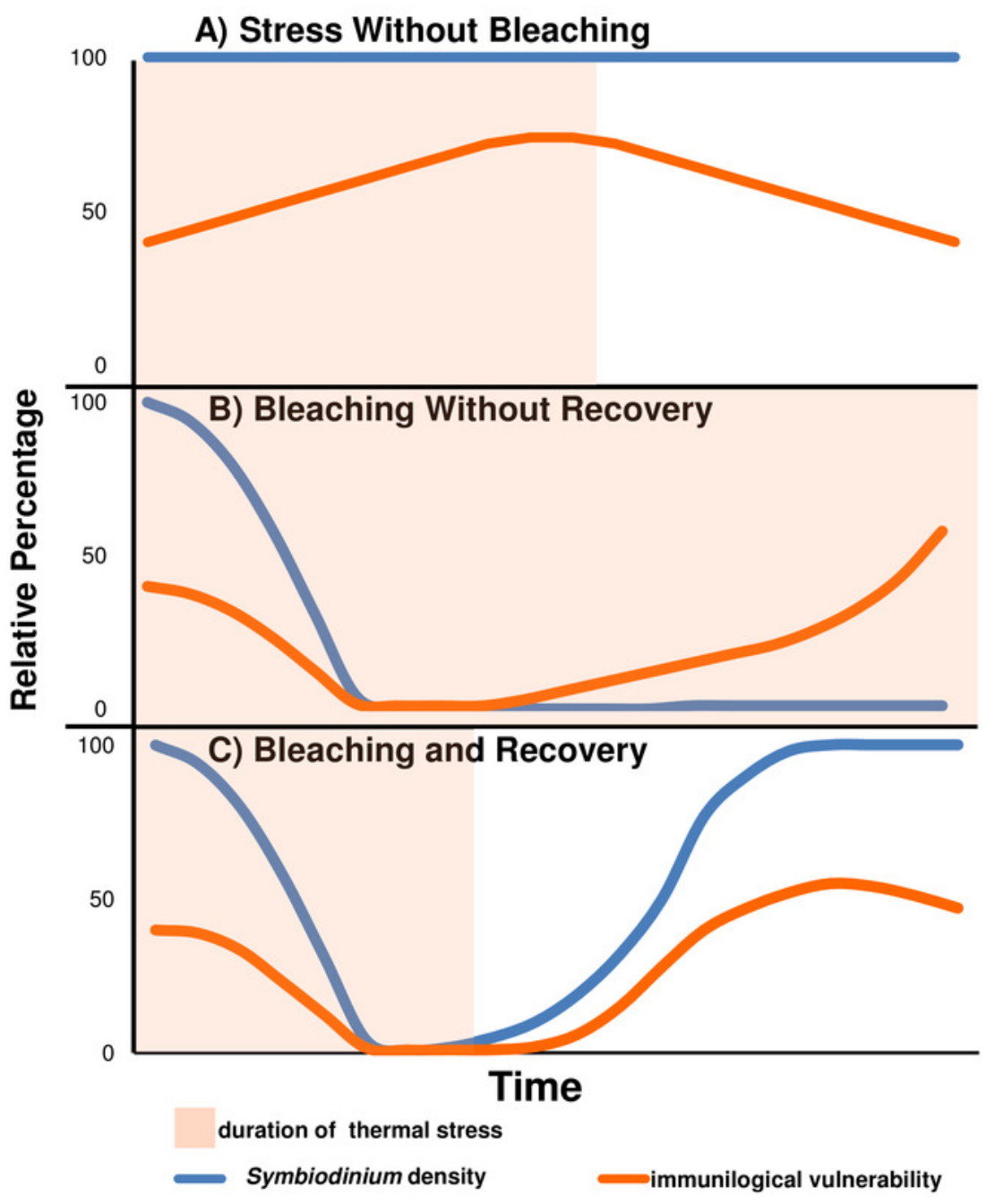

